Fikrah: Jurnal Ilmu Aqidah dan Studi Keagamaan issn 2354-6174 eissn 2476-9649

Tersedia online di: journal.iainkudus.ac.id/index.php/fikrah

Volume 8 Nomor 12020 , (43- 52)

DOI: $10.21043 /$ fikrah.v8i1.7103

\title{
Studying Religion through the Internet among Millennial Muslims: Causes and Consequences
}

\author{
M. Affan \\ Independent Researcher \\ mehmed.affan@gmail.com
}

Ajid Thohir

UIN Sunan Gunung Djati Bandung

ajid.thohir@uinsgd.ac.id

\begin{abstract}
Abstrak
Artikel ini akan mendiskusikan persoalan belajar agama melalui internet sebagai sebuah tren baru dikalangan Muslim Milenial Indonesia. Kajian ini bertujuan untuk menjelaskan mengenai sebab dan akibat yang dapat muncul dari fenomena ini. Hasil kajian ini diharapkan dapat memberi sumbangan pemikiran dalam diskursus mengenai Studi Islam di Era 4.0 yang penuh disrupsi. Metode yang dipergunakan dalam kajian adalah metode penelitian pustaka. Dari kajian yang dilakukan, diperoleh kesimpulan bahwa fenomena ini muncul sebagai dampak dari perkembangan teknologi informasi dan komunkasi yang begitu pesat. Sisi positif dari fenomena ini adalah efisiensi dalam pembelajaran agama. Namun fenomena ini juga memunculkan sisi negatif pada ancaman infiltrasi konten radikalisme beragama yang juga disebarkan secara online. Sehingga dibutuhkan kewaspadaan dalam memaknai fenomena ini yang telah menjadi tren bukan hanya di Indonesia melainkan juga diseluruh dunia.
\end{abstract}

Kata kunci: Agama, disrupsi, internet, Muslim Milenial, revolusi industri 4.0 


\begin{abstract}
This article will discuss the issue of studying religion through the internet as a new trend among Indonesian Millennial Muslims. This study aims to explain the causes and consequences that can arise from this phenomenon. The results of this study are expected to contribute thoughts in the discourse on Islamic Studies in Era 4.0 which is full of disruption. The method used in the study is library research methods. From the studies conducted, it was concluded that this phenomenon emerged as an impact of the rapid development of information and communication technology. The positive side of this phenomenon is efficiency in religious learning. However, this phenomenon also raises the negative side of the threat of religious radicalism content infiltration that is also spread online. So that, caution is needed in interpreting this phenomenon which has become a trend not only in Indonesia but also throughout the world.
\end{abstract}

Keywords: disruption, millennial muslims industry revolution 4.0, internet, religion

\title{
Introduction
}

The 21st century is an era of the industrial revolution 4.0. This era is closely related to the use of information and communication technology that is so massive in moving human life in various fields. Thus, it can also be called the era of information and communication technology. One of the important keywords that represent this era is the internet. One measure of modernity itself is measured by online or offline status on the internet. So, the internet becomes an important thing that is inseparable from modern human life. Islamic learning has also taken up vast space on the internet. There are so many people who claim to be preachers to spread their lectures on various religious topics via the internet. Each preacher has his own genre and followers. In this way, the image is built and popularity is developed. However, this condition also results in a propaganda banality (Risdiana \& Ramadhan, 2019, hal. 151). Although this has a negative value, the presence of preachers on the internet with online preaching has drowned those who do not give religious lessons through the internet. Offline preachers or offline religious teachers, although they have better qualifications, are often excluded from the arena of Islamic $d a^{\prime} w a h$. This is due to the demands of modernity that have made the internet a new backbone in Islamic da'wah. The main consumers of this online propaganda are the generation born or raised in the internet era. They are often identified as millennial. Millennial is the generation born between 1981 and 2000 (Tanner, 2010, hal. 10). Among Muslims, this generation can be called Millennial Muslims. 
The internet user's penetration in Indonesia itself has grown rapidly. In 2017, the number of internet users reached 143.26 million. The 13-18-year age group controls 16.68 percent of this amount. Meanwhile, the 19-34 year age group controlled 49.52 percent (Asosiasi Penyelenggara Jasa Internet Indonesa (APJII), 2017). Thus, more than half of the number of internet users in Indonesia are from millennial. Internet users in Indonesia continue to grow in the following years, where there was a surge of about 27.91 million. Thus, in 2018 there will be around 171.17 million people from Indonesia's population of 264.16 million (APJII \& Polling Indonesia, 2019). Numbers of that size have shown how the internet has become so widespread in Indonesia.

The large number of internet users in Indonesia especially among Millennial Muslims deserves special attention. The efforts of Millennial Muslim generations to search for religious knowledge through the internet have become a separate phenomenon that needs to be examined for its causes and consequences. This is important, considering that this phenomenon can have both positive and negative impacts simultaneously. What happened to Ivan Armandi in Medan in 2016 can be an example of how the internet can provide negative inspiration ( $H$. Affan, 2016). Instead of searching for religious knowledge through the internet, the teenager is actually trapped into the provocation of IS (Islamic State) groups to attack houses of worship of other faiths (M Affan, 2018, hal. 200-201).

Departing from the above problems, the study aims to describe the causes and consequences that can be obtained by Millennial Muslims who seek religious knowledge through the internet. The results of this study are expected to contribute thoughts Muslims in Indonesia in facing challenges in the era of the industrial revolution 4.0. For Islamic studies themselves, the results of this study are expected to expand as well as develop research subjects on Millennial Muslim, especially in Indonesia.

\section{Method}

The method used in this research is library research method. Sources used are scientific articles on millennial muslims, internet, religion and proxy wars. Meanwhile, this research uses critical-analysis descriptive method. The author uses descriptive methods to describe and discuss studying religion through the internet among millennial muslims systematically (Bakker \& Zubair, 1990). The critical-analysis method is used to criticize ideas and concepts about the causes and Consequences of millennial muslims studying 
religion through the internet, so get the answer problems with maintaining objectivity (Nurnaningsih, 2013).

\section{The Causes of Millennial Muslims Studying Religion through the Internet}

Millennial generation is also known as generation Y. The term generation $\mathrm{Y}$ began to be introduced by the media in the United States around 1993. This generation grew together with the internet boom era. So, it is not so surprising if one of the characters of this generation is the ability and habit of using instant communication technologies such as email, SMS, instant messaging and social media such as Facebook and Twitter (Putra, 2016, hal. 129). The development of communication and information technology has made the use of the internet a necessity. Initially, in addition to displaying sites for business and social political interests, the internet was also used as a chatting platform before smartphones facilitated communication applications such as WhatsApp and so forth. However, as time goes by and supporting facilities for the internet have progressed, the use of the internet has become so widespread and massive. A person's existence is also measured by his presence in various internet-based social media networks. In turn, the need to continue to exist in cyberspace is becoming a daily activity for many people.

In the next development, when smartphones have been introduced and become a new platform from the internet, millennials are the ones who respond quickly. The use of PCs and notebooks as a surfing platform on the internet began to be abandoned by switching to smartphones that are more mobile. In turn, smartphone use is widespread and has become an important part of millennial life (Weinbaum, Girven, \& Oberholtzer, 2016, hal. 4). With smartphones, millennial is easier to access the internet. It also triggers millennial dependence on the internet. So, everything in millennial life can hardly be separated from the internet, including learning. In millennial era, there is a tendency for certain patterns of learning to be far from violence, loose learning systems and participatory methods. This is different from conventional education patterns that have binding rules. Meanwhile, the internet facilitates social media networks that provide learning patterns that run liberally following trends and market needs. In addition, social media networks on the internet also provide a study of contemporary issues of the Ummah (Nugraha, 2018, hal. 58). With a loose and non-binding system, 
religious learning through the internet invites enormous interest for millennials.

Even though it looks liberal, religious studies on the internet have more conservative content. This is caused by the salafism group's good response to the internet. Salafi groups use the internet as their da'wah media while promoting their collective identity (Iqbal, 2013, hal. 81). Thus, millennials who study religion through the internet more often receive religious information and knowledge from this group. Without realizing it, most millennials are at the forefront of religious conservatism and often become mouthpieces of established religious authority. Some go further by being radical as a form of seeking out their manhood. However, millennials also present religious issues in a more interesting and dynamic way, even crossing traditional boundaries (Epafras, 2016, hal. 14). In the context of religion, the behavior of millennials who seek religious knowledge and information through the internet can cause big problems because the information and knowledge obtained without being verified can be fake news, hoaxes or hate speeches (Rusdiyanto \& Gonibala, 2019, hal. 104). Even the radical character that is vulnerable to be adopted by millennials through religious studies on the internet may occur due to the unverified religious knowledge and information. On the other hand, the huge dependence on the internet has made Millennial Muslims a target of proxy wars. The formation of a proxy through narratives distributed through the internet is the biggest threat as well as the challenges that must be faced by Indonesian Muslims, especially from millennials (Muhammad Affan, 2018, hal. 167).

The internet has succeeded in forming a new habit for many people in the world. In fact, the whole world has been encouraged to make the internet a vehicle for communication, information, business, and social affairs. Basically, this is part of globalization, where globalization has made the internet a particularly important thing. On the other hand, the internet has also strengthened the process of globalization. Thus, geographical, social political and cultural barriers are meaningless. The presence of the internet itself is the first reason millennials seek religious knowledge in the virtual space. Without the presence of the internet, of course there will be no religious learning activities through the internet. Thus, the internet is the first cause for millennials in seeking religious knowledge online

The second cause is the millennial themselves. The presence of millennials who together with the internet boom has made them the internet 
generation. The era in which they are growing and developing is an era where sophisticated information and communication technology is developing in such a way. Thus, the environment that forms the character of millennials is an environment that requires adaptation to the presence of the internet and all kinds of things. Millennials become accustomed to and have their own needs on the internet.

For millennials, a life without surfing the internet and social media networking is almost unimaginable. Thus, religious learning behavior via the internet becomes a common thing even part of their daily activities. On the other hand, some groups also give a quick and good response to the internet presence by making it their platform for preaching. This response has met the needs of millennials in the field of religion. Thus, the internet has become an easy solution for millennials to study religion according to their characters who tend to like learning models with loose systems and non-binding rules.

\section{Consequences of Studying Religion through the Internet}

Religious learning behavior through the internet among millennials has its own consequences. At least there are some consequences received by millennial who choose to study religion through the internet. The consequences themselves are positive and negative. The positive consequences obtained by millennial are time and space efficiency. In the era of the industrial revolution 4.0 which demands effectiveness and efficiency in the use of space and time, religious learning through the internet can be a quite appropriate solution. In this way, Millennial Muslims can continue to adapt to the times that are so fast and sophisticated.

However, despite this positive consequence, the negative consequence of studying religion through the internet are the things that most require attention. This is due to the threat of proxy wars targeting Millennial Muslims. Terrorist groups such as the IS (Islamic State) have been identified as carrying out a method of proxy war not only in Indonesia but also throughout the world which has a Muslim population. For Indonesia itself, the threat is very large because of the large Muslim population and the large number of millennial Muslims. Terrorist groups such as IS (Islamic State) infiltrate through the internet by distributing narratives of terrorism in camouflage of religious teachings (M Affan, 2018). They position themselves as religious teachers in front of religious knowledge seekers on the internet. In this way, they try to dictate their readers and audience to follow their will (M Affan, 2018). 
Uniquely, the millennial generation itself is a generation that is not concerned with the issue of international terrorism and shows low support for counter-terrorism efforts (Thrall \& Goepner, 2015, hal. 10). Thus, the narrative of terrorism that is inserted into religious narratives on the internet does not receive vigilance from millennials. Terrorist groups such as the IS (Islamic State) itself use the internet to recruit members and sympathizers by using pictures and words (Awan, 2017, hal. 147). This condition directly or indirectly poses a high risk to millennials who are not careful in filtering information they obtain through the internet. The IS (Islamic State) ideology itself combines takfiri, salafi, sectarian and millennial components in its jihadist narratives (Anthony, 2014, hal. 1). Thus, it becomes clear that millennials are the main target of recruiting terror groups such as the IS (Islamic State) to carry out their terror agendas. IS (Islamic State) itself is not an anti-globalization movement. IS (Islamic State) and terror organizations such as are part of globalization both as participants and as the interpreter of globalization itself (Iqbal \& Zulkifli, 2016, hal. 37-38). Millennials and the internet are, in fact, also part of globalization. This also means that the three can go hand in hand in a similar era. So, it is not surprising that terrorism such as IS (Islamic State) can continue to exist even though it has been fought throughout the world.

In the context of security, the era of the industrial revolution 4.0 can be interpreted as an era of proxy wars. War in the form of proxy wars will be dominant throughout the world. The region that had already experienced this proxy war turmoil was the Middle East region where the Syrian Civil War became the most active proxy war (Alterman, 2013, hal. 1). If currently the proxy war has begun to take place in the Middle East region, in the future the presence of a conflict with the character of a proxy war is predicted to be increasingly dominant because this war model does not cost much (Mumford, 2013, hal. 40). Therefore, the threat of a proxy war is a major challenge for millennials because this war model is carried out with narratives that are easily distributed via the internet in various camouflage. One camouflage used is religious camouflage. Therefore, religious narratives on the internet which become religious learning materials for Millennial Muslims have the potential to be proxies forming narratives. Innocent Millennial Muslims will think that they are studying religion. However, without realizing they are actually being influenced and led to become proxies that are ready to carry out various actions such as lone wolf attacks, demonstrations and mass riots. This is a negative consequence that can be accepted by millennial Muslims who study religion through the internet. 


\section{Conclusion}

Religious learning behavior through the internet has become a trend among Millennial Muslim generations caused by three things. First, the presence of the internet that facilitates religious learning behavior in cyberspace. Second, the presence of millennial generation in line with the development of the internet that is increasingly advanced and widespread. So millennial generation is the generation that was born and developed together with the internet. Third is the response of religious groups in providing religious information content on the internet. The behavior has positive and negative consequences. The positive consequence of this behavior is the efficiency and ease of access to religious information on millennial Muslims who have limited time and space to study religion. Meanwhile, the negative consequence is ineffectiveness in studying religion. Millennials may be trapped into a wrong understanding of religion and can even be used by terrorist groups such as the IS (Islamic State) to be a proxy for them to wage a war on terror.

Seeing the large negative consequences that can be obtained by Millennial Muslims when studying religion through the internet, this behavior should be reviewed again. We cannot prevent the development of an era that demands the efficiency and effectiveness of time and space. Studying religion through the internet among millennial Muslims cannot also be blocked or stopped altogether. The thing that deserves attention is how to reduce the negative consequences that can be obtained by millennial Muslims who study religion through the internet. Various studies on religious learning behavior through the internet need to be intensified to find a solution to this problem going forward.

\section{Referensi}

Affan, H. (2016). Terduga Pelaku Serangan Di Gereja Medan Terinspirasi Teror Prancis.

Affan, M. (2018). Ancaman Dan Tantangan Muslim Indonesia Di Era Perang Proksi. Analisis, 18(2), 147-170.

Affan, M. (2018). The Threat of IS Proxy Warfare on Indonesian Millennial Muslims. Indonesian Journal of Islam and Muslim Societies, 8(2), 199. https://doi.org/10.18326/ijims.v8i2.199-223

Alterman, J. B. (2013). The Age of Proxy Warfare. Middle East Notes and Comment. CSIS Middle East Program.

Anthony, C. (2014). Dabiq: IS's Apocalyptic 21st Century Jihadist Manifesto. Journal 
Political Sciences and Public Affairs, 2(4).

APJII, \& Polling Indonesia. (2019). Laporan Survei Penetrasi dan Profil Perilaku Pengguna Internet Indonesia 2018 (Survei 2018). Asosiasi Penyelenggara Jasa Internet Indonesia (APJII).

Asosiasi Penyelenggara Jasa Internet Indonesa (APJII). (2017). Penetrasi dan Perilaku Pengguna Internet Indonesia: Survei 2017 (Survei 2017). Jakarta: Asosiasi Penyelenggara Jasa Internet Indonesia (APJII).

Awan, I. (2017). Cyber-Extremism: Isis and the Power of Social Media. Society, 54(2), 138-149. https://doi.org/10.1007/s12115-017-0114-0

Bakker, A., \& Zubair, A. C. (1990). Metodologi Penelitian Filsafat. Yogyakarta: Kanisius.

Epafras, L. C. (2016). Religious e-Xpression among the Youths in the Indonesian Cyberspace. Jurnal Ilmu Komunikasi, 13(1), 1-18.

Iqbal, A. M. (2013). Agama dan Adopsi Media Baru: Penggunaan Internet oleh Gerakan Salafisme di Indonesia. Jurnal Komunikasi Indonesia, 2(2), 77-87.

Iqbal, A. M., \& Zulkifli. (2016). Islamic Fundamentalism, Nation-state and Global Citizenship: The Case of Hizb ut-Tahrir. Indonesian Journal of Islam and Muslim Societies, 6(1).

Mumford, A. (2013). Proxy Warfare and the Future of Conflict. The RUSI Journal, 158(2), 40-46. https://doi.org/10.1080/03071847.2013.787733

Nugraha, M. T. (2018). Fundamentalisme Pendidikan Agama di Jejaring Sosial. Al Tahrir, 18(1), 41-62.

Nurnaningsih. (2013). Urgensi Teori Kritik Dalam Analisis Kajian Islam (Suatu Analisis Kajian Amr Ma'Rûf Nahy Munkar). Jurnal Ijtimaiyya, 6(1).

Putra, Y. S. (2016). Theoritical Review : Teori Perbedaan Generasi. Among Makarti, 9(18), 123-134.

Risdiana, A., \& Ramadhan, R. B. (2019). Dakwah Virtual sebagai Banalitas Keberagamaan di Era Disrupsi. FIKRAH, 7(1), 133. https://doi.org/10.21043/fikrah.v7i1.4800

Rusdiyanto, R., \& Gonibala, R. (2019). Pola Keberislaman Generasi Milenial Manado di era Post-Truth. FIKRAH, 7(1), 95. https://doi.org/10.21043/fikrah.v7i1.4814

Tanner, L. (2010). Who are the Millennials? Defence R\&D Canada-Centre for Operational Research and Analysis.

Thrall, A. T., \& Goepner, E. (2015). Millennials and U.S Foreign Policy: The Next Generation's Attitudes toward Foreign Policy and War (and Why They Matter). Washington D.C: CATO Institute.

Weinbaum, C., Girven, R., \& Oberholtzer, J. (2016). The Millennial Generation: Implications for the Intelligence and Policy Communities. Washington D.C: RAND Corporation. 
This page intentionally left blank 